DOI: $10.35619 /$ iiu.v1i10.154

\author{
Сухомлинська Ольга \\ доктор педагогічних наук, професор, \\ дійсний член НАПН України, \\ головний науковий співробітник \\ ДНПБ України ім. В. О. Сухомлинського, \\ м. Київ, Україна \\ ORCID: 0000-0002-2033-285X \\ e-mail:2991946@gmail.com
}

\title{
МЕТОДИЧНА СПАДЩИНА ВАСИЛЯ СУХОМЛИНСЬКОГО: ЧЕРЕЗ ІСТОРИКО-ПЕДАГОГІЧНЕ ПІЗНАННЯ ДО ПОШУКІВ ВІДПОВІДЕЙ НА ВИКЛИКИ СЬОГОДЕННЯ
}

\begin{abstract}
Анотація. У статті методична спадщина В. Сухомлинського розглядається крізь призму недавньої історії педагогіки та сучасних підходів до розроблення методичної проблематики з метою більш глибокого осмислення теми в умовах актуалізації питань організації діяльності суб'єктів освітньо-виховного процесу в закладах середньої освіти. Виокремлено методичну спадщину педагога як важливу складову його цілісної системи поглядів на освіту і виховання дітей і молоді. Здійснено історіографічний аналіз останніх праць дослідників, які вивчали методичну спадщину педагога і на цій основі виявлено особливий внесок В. Сухомлинського у розвиток методики навчання в початкових класах, методики української літератури та лінгводидактики. Розкрито особливий внесок педагога у розвиток методики виховання, який відзначається поєднанням двох методик - навчання і виховання - в єдине невіддільне ціле, що втілилося у створених ним інноваційних формах діяльності, спрямованих на розвиток дітей, які кардинально відрізнялися від існуючих на той час підходів і форм організації навчально-виховного процесу (школа радості, уроки мислення, уроки творчості, інтелектуальний фон школи, олюднення знань, радість пізнання, гармонія педагогічних впливів тощо). Крім історіографії матеріалів про методичну спадщину педагога, у статті розкрито й малодосліджену тему - аналіз відвідуваних Сухомлинським уроків учителів керованої ним школи, а також репрезентовано матеріали з частково неопублікованого рукопису, які розширюють і поглиблюють знання про Сухомлинського як методиста.

3'ясовано, що методична спадщина педагога, яка містить як навчальну, так i виховну складову і являє собою цілісний загальнометодичний підхід до педагогічних процесів, що відбуваються в закладах освіти, найбільше відповідає новітнім тенденціям в освіті.

Зроблено висновок, що сучасне реформування освіти як реалізація ідей і положень Нової української школи, сприяє більш широкому ознайомленню $з$ творчим доробком педагога та створює передумови для розгляду методичних ідей В. Сухомлинського як складових процесу розвитку сучасної освіти в Україні. Через історико-педагогічне пізнання й переосмислення вводяться плідні ідеї, форми й методи організації освітньовиховного процесу, що сприяють утвердженню погляду на В. Сухомлинського як провісника реформаційних процесів в освіті, реформатора педагогіки.
\end{abstract}

Ключові слова: методика, спадщина, В. Сухомлинський, дослідження, лінгводидактика, початкова освіта, навчання, виховання, аналіз, урок, педагогічний процес, реформи, реновації.

Постановка проблеми. Методичне забезпечення педагогічного процесу в закладах освіти - одне з головних питань практичної організації навчання і виховання 
дітей, від вирішення якого залежить великою мірою реалізація мети і завдань освіти. Ця проблема набуває особливої гостроти в періоди становлення нових освітньовиховних парадигм, коли постає багато питань щодо вироблення й конкретизації шляхів досягнення нових цілей. Саме такі процеси відбуваються сьогодні в українській освіті, що, серед іншого, викликає особливий інтерес до цікавого досвіду недавнього минулого, який має не лише ретроспективний, а й реноваційний характер.

Аналіз останніх досліджень 3 проблеми. Питання методичного й навчальнометодичного забезпечення навчально-виховного процесу в закладах освіти, і зокрема дошкільних і середніх, викликають інтерес як у науковців, так і у практичних працівників. Відзначимо особливо, що провідні українські фахівці, які є авторитетами у своїх напрямах педагогічних досліджень, приділяють багато уваги вивченню i популяризації спадщини В. Сухомлинського, i, зокрема, іiї методичної складової, що, на нашу думку, одночасно виступає й важливим фактором її експертного оцінювання. Зокрема, велику увагу питанням мовленнєвого розвитку дітей дошкільного віку приділяє фахівчиня 3 дошкільної педагогіки А. Богуш, авторка програм з методичного забезпечення дошкільних закладів освіти $(2002,2007,2008)$. Ця науковиця не обходила увагою і методичну спадщину В. Сухомлинського в тому ії аспекті, що стосується навчання і виховання дошкільників (2012). Інша вчена, О. Савченко, відомий український дидакт, фахівчиня з початкової освіти, серед своїх основних наукових інтересів має розвідки 3 питань розробки змісту освіти $(2008,2012)$, компетентнісного підходу в навчальному процесі (2011), а також тримає в полі зору творчий спадок педагога, і впроваджує його в навчальну літературу для початкових класів: зокрема, художню спадщину В. Сухомлинського як складову розвитку дитини. Щодо виховного процесу, то тут перше місце серед публікацій з означеної теми належить I. Беху, який у своїх працях, присвячених загальним питанням виховання дітей і молоді, звертається і до спадщини Сухомлинського (2006, 2008, 2017, 2018).

Відзначимо й істориків педагогіки, які вивчали дидактичні аспекти педагогічної спадщини Сухомлинського, а тому більшою чи меншою мірою розкривали методичні пошуки педагога. Це перш за все праці М. Антонця (2008, 2009), Г. Ткаченко (2000), Т. Челпаченко (2012) та інших. Однак спеціальних досліджень, які б предметом свого вивчення обрали методичну спадщину Сухомлинського, ми не знайшли.

Мета статті: розкрити потенціал методичної спадщини Василя Сухомлинського через висвітлення історії розвитку його методичних ідей та історіографії досліджень як ймовірного ресурсу для реноваційного наповнення практичної діяльності реформованої української школи.

Виклад основного матеріалу дослідження. Обравши темою дослідження методичні ідеї В. Сухомлинського, перш за все визначимося 3 понятійнотермінологічним апаратом, розкриємо, що таке методика як певна галузь педагогіки і як вона співвідноситься зі спадщиною Сухомлинського. Щодо навчального процесу термін «методика» визначає шляхи досягнення мети і завдань окремого навчального предмета, на відміну від дидактики, яка охоплює весь навчальний процес як цілісність. Нині методики навчання окремих предметів часто називають частковими дидактиками. Саме методика, як зазначав С. Гончаренко, розв'язує три основні навчальні завдання й шукає відповіді на три запитання: Чого навчати? Як навчати? Як учитися? (Гончаренко, 2000). Отже, головне питання методики навчального предмета (або ж часткової дидактики) - як, у який спосіб поєднати всі три складові педагогічного процесу, аби досягнути не лише мети окремого уроку, а навчального предмета в цілому.

Але ж знаємо, що поняття «методика» стосується не лише навчального предмета 3 чіткою вказівкою на окремий навчальний предмет або рівень освіти - початкова школа, а й великою мірою виховного процесу, де під цим терміном розуміється сукупність способів вирішення різноманітних виховних завдань. Порівняно 3 методами навчання вони більш різновекторні й дискусійні, мають декілька різних 
класифікаційних систем, поширюються на широке коло об'єктів, і хоча й носять відносний характер, але разом з тим виступають стрижнем виховного процесу, засобом вирішення мети і завдань виховання в конкретних умовах (Енциклопедія освіти, 2008). Ці два напрями - методика навчання і методика виховання - споріднені між собою своїми загальними цілями й завданнями, але, як правило, співіснують автономно, особливо в останні десятиліття, коли швидко і кардинально змінюються парадигми як навчального, так і виховного процесів, і вони все далі розходяться між собою, породжуючи цим самим нові питання і нові проблеми.

Висунуті на порядок денний стратегічними завданнями розвитку сучасної освіти, а також і кризовими станами, що виникають там час від часу, питання методики спонукають педагогів звертатися до вітчизняних надбань педагогічної думки як до маркеру i критерію висунутих новаторських ідей, а також для гармонізації ретроспективного й проективного підходів. I тому не випадковим $є$ звернення до методичної спадщини Василя Сухомлинського, яка нині особливо затребувана i в контексті минулорічного 100-річного ювілею педагога, і тим фактом, що його доробок найбільше згадується у контексті розробки концепцій і програм Нової української школи.

Спочатку зазначимо, що власне спеціальних методичних праць у В. Сухомлинського небагато - окремі статті і одна книга - «Методика виховання колективу», проблематика якої повністю лежить в площині теорії колективу, а, отже, претендує на ще один методичний напрям, якого тут не будемо торкатися (Сухомлинський, 1971). Але не можемо стверджувати, що педагог обходив своєю увагою методичні питання, навпаки, він цікавився ними впродовж усього свого творчого життя. Приміром, ще на початку своєї діяльності у середині 1940-х років, і в більш пізній час, у середині 1960-х, В. Сухомлинський друкує кілька статей методичного характеру, спрямованих на покращення процесу вивчення окремих навчальних предметів, які за своєю сутністю $є$ реакцією на виклики часу: підвищення якості знань з мови і літератури, арифметики, грамотності тощо (Сухомлинський, 1946, 1951, 1951, 1952, 1953, 1954, 1959).

Друга половина 1960-х років позначена зверненням Василя Олександровича до лінгводидактики як до загальної теорії навчання української мови в загальноосвітній школі, а також до питань викладання української літератури в школі. Красномовним прикладом комплексного і цілісного підходу до методики шкільної філологічної освіти $€$ його статті про викладання словесності (рідної мови і літератури в загальноосвітній школі), які стали класичними, затребуваними й нині не втратили своєї актуальності (Сухомлинський, 1965, 1968, 1969 a,b).

Але найбільше інформації й найповніше представлення думок педагога про методику навчання надають останні програмні твори педагога, які вийшли наприкінці його життя і після його відходу. Це «Павлиська середня школа», де є спеціальний параграф «Розумове виховання і методика навчання» (Сухомлинський, 1977), «Серце віддаю дітям» 3 параграфом «Як ми вчилися читати й писати» (Сухомлинський, 1918) i особливо «Сто порад вчителеві», де в першій дидактично-методичній ії частині 350 порад 16 носять конкретно методичний характер (Сухомлинський, 1976, с. 445-507).

Ці праці, як і інші, ставали предметом вивчення як вітчизняних, так і зарубіжних вчених, хоча їх кількість і не така значна. Перш за все згадаємо статті В. Святовця, який одним 3 перших звернувся до розкриття поглядів В. Сухомлинського на методику навчання і викладання української мови і літератури в школі, а також до аналізу Сухомлинським відвіданих уроків (Святовець, 1984, 1978, 1978). До характеристики методичних ідей педагога звертався у 1980-х роках і відомий науковець М. Стельмахович, який назвав Сухомлинського «видатним творцем методики вивчення рідної мови» (Стельмахович, 1985, 1988).

У період незалежності дослідниця Л. Мамчур широко висвітлила методичну спадщину Сухомлинського спочатку в кандидатській дисертації, яку захистила в 1998 
році, а згодом, у 2009 р. видала навчально-методичний посібник «Лінгводидактична спадщина В. О. Сухомлинського», де розкрила генезу поглядів педагога на викладання і навчання рідної мови в загальноосвітній школі (Мамчур, 2009), Інша дослідниця, I. Баранюк у монографії «Слово, природа, краса в педагогічній системі Василя Сухомлинського» (2017), розглядаючи й аналізуючи три основоположні концепти педагогіки Сухомлинського - «слово», «природа», «краса», що мають першочергове значення для розбудови освітнього процесу в початковій школі, весь третій розділ своєї книги присвятила «практичній лінгводидактиці», а особливо аналізу відвіданих Сухомлинським уроків учителів початкових класів, який реконструювала, описала, й наповнила досить розлогими коментарями, що дало можливість не лише ознайомитися 3 окремими думками й баченнями педагога щодо перебігу конкретного уроку, а й отримати коментар авторки (Баранюк, 2017). Нею ж складено певний набір рекомендацій і порад Сухомлинського вчителям початкової школи, які авторка вважає «золотими правилами» дидактики (Баранюк, 2017, с.110-112).

Науковиця Л. Пархета в своєму дисертаційному дослідженні «Українська література як навчальний предмет у спадщині В. О. Сухомлинського» (2006) зупинилася, серед іншого, і на розкритті підходів педагога до методики викладання цього предмета як на уроках, так і в позаурочній діяльності, і зокрема на формах і видах позакласного читання (Пархета, 2006).

Тож, історіографічний аналіз літератури засвідчив, що методична спадщина Сухомлинського у частині, що стосується навчального процесу, виступала предметом аналізу в порівняно невеликій кількості праць вітчизняних дослідників і торкалася переважно методики навчання украӥнської мови і літератури та початкової освіти. Це, на нашу думку, пояснюється перш за все тим, що Сухомлинський був словесником і за своєю освітою, і за покликанням, а також багато уваги приділяв початковій школі, справедливо вважаючи, що саме там закладаються основи подальшого розвитку дитини, ïi успіху в навчанні.

Найбільш цікавим 3 методичного виміру сьогодення виступає ознайомлення 3 аналізами відвідуваних уроків, де Сухомлинський виступає не лише спостерігачем, який бачить цілісну картину уроку, аналізує роботу вчителя, змістове наповнення заняття, роботу дітей, водночас перебуваючи «над» процесом. Ознайомлення 3 аналізами та відповідними працями, де цей аналіз розглядається, надав нам можливість дійти висновку, що ця форма методичної роботи виступила потужним імпульсом і ресурсом для організації і проведення методичної роботи в загальношкільному масштабі, про що він і писав у книзі «Розмова 3 молодим директором»: «Досвід переконує, що відвідування й аналіз уроків - найважливіша робота директора; від іiі високого наукового рівня залежить дуже багато: інтелектуальне багатство життя педагогічного i учнівського колективів, методична майстерність педагогів, багатогранність запитів та інтересів вихованців. Від повсякденного удосконалення уроку, що відбувається завдяки вдумливому аналізу керівників, залежить культура всього педагогічного процесу в школі» (Сухомлинський, 1988, с. 223).

В цьому виді діяльності Василь Олександрович виявив себе творчою особистістю, «педагогом - митцем», як характеризував таких учителів відомий педагог 1920-1930-х років Яків Мамонтов. У своїх записах щодо перебігу уроку Сухомлинський інколи робив помітку: «Я зробив би так». До прикладу: аналіз уроку української мови в 7-Б класі. Тема уроку: робота над твором «Найяскравіша подія дитинства, що запам'яталася». Педагог зазначав: «Вчительці було б добре назвати декілька спогадів.

Пригадай, як:

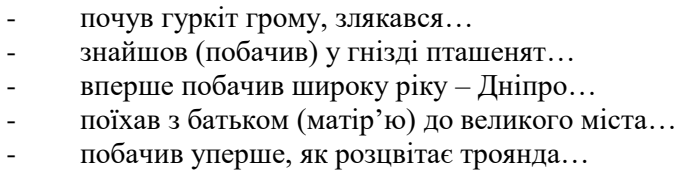


- смерть бабусі (чи дідуся), взагалі якесь горе, біда у сім’і (цікаво, чи хтонебудь напише про це?)...

Я радив би у вступному слові говорити не про спогади дитинства взагалі, а про свої особисті, живі спогади - це було б далеко краще» (Зошит. Аналіз уроків за 1969/1970 рік).

Варто відзначити, що ознайомлення 3 аналізом відвідуваних Сухомлинським уроків ще тільки розпочато. Отож сподіваємося, що буде знайдено багато цікавого і перспективного у цій царині.

Тепер звернемося до методичної спадщини Сухомлинського в галузі виховання. Тут історіографічний екскурс пропонує нам значно більше розвідок дослідницького характеру. Якщо подивитися на підготовлені дисертаційні дослідження, присвячені загалом спадщині Сухомлинського, то переважна більшість із 73-х захищених присвячені розкриттю окремих виховних напрямів (ідейно-моральне, етичне, моральне, фізичне, трудове громадянське, патріотичне, гуманістичне виховання тощо). 3 окремих напрямів написана досить велика кількість дисертацій. Наприклад, 3 різних аспектів морального виховання - 7 дисертацій і така ж кількість 3 гуманістичного виховання (Сухомлинська, 1981, 2001, Заліток, 2008). I лише 7 з них (Л. Абрамова (1978), В. Свиридов (1981), А. Луцюк (1996), Т. Остапйовська (1996), Г. Ткаченко (2000). І. Наливайченко (2001), Л. Заліток (2011) (Заліток, 2008) можна опосередковано віднести до теми нашого розгляду. Але навіть у цих працях важко вичленити саме методичну складову, бо в структурі дисертацій вона не заявлена, хоча всі вони присвячені виховній проблематиці, де, здавалося б, не обійтися без розкриття методики виховної роботи в тому чи іншому напрямі.

I цей факт можна пояснити. Як видається, Сухомлинський, мабуть, один 3 небагатьох педагогів, як теоретиків, так і практиків, який поєднав у своєму баченні, своїх підходах не лише сукупність питань організації і методичного спрямування освітнього процесу, а й долучив до них весь педагогічний процес, а особливо виховний. При цьому його холістичний, изілісний підхід не дозволяє 3 легкістю відділити, відокремити питання методики навчального процесу, дидактики від методики виховання. Візьмемо, наприклад, найпопулярнішу його знахідку - уроки на природі (школа просто неба, школа радості), описані в багатьох його творах, а насамперед в «Серці віддаю дітям». На іï прикладі можна прослідкувати, як Сухомлинський ставить собі за мету дидактичні завдання (розвиток мислення: від конкретного до абстрактного, мовлення, зв'язного викладу думок, розвиток уяви, дозованість донесення знань тощо), методичні завдання (навчання читання, письма, рахунку), але разом 3 тим і виховні завдання (виховання почуття краси, бережливого ставлення до природи, патріотичних почуттів, естетичного сприйняття навколишнього світу, виховання доброзичливості, піклування і доброти тощо) (Сухомлинський, 2018).

I так стосовно багатьох складових його педагогічної системи: уроків мислення $i$ милування природою, формування культури бажань $і$ культури почуттів, створення інтелектуального фону школи, формування $y$ школяра радості пізнання $i$ стимулювання цьвого процесу тощо. У них настільки цілісно й інтегровано представлено розв'язання педагогічних завдань, що важко, а іноді й неможливо провести демаркаційну лінію між одним і другим, тобто між навчанням і вихованням.

Однак, не можна стверджувати, що Сухомлинський обійшов своєю увагою ці питання, не віддиференціював і не вичленував їхню специфіку, про що трохи згодом. I все ж провідною концептуальною його ідеєю була єдність освіченості й вихованості, а відтак єдність методик їхнього застосування. Звернемося до праць педагога 3 тим, аби віднайти його думки щодо цих питань. I хоча в його працях мало зустрічаємо прямого посилання на методи, в багатьох творах він починає розмову з читачем зі слова «як», що вже передбачає спосіб дії, тобто вказує на методику. Найбільш повно теоретичні положення щодо виховного процесу Сухомлинський виклав у праці «Етюди про комуністичне виховання», до якої, через розгорнуту дискусію і критику деяких іiі 
положень, рідко зверталися і звертаються дослідники, а дарма. В одному з розділів цієї публікації педагог викладає свої підходи до методів виховання на прикладі морального виховання школярів. Серед них на перше місце педагог виводить слово вчителя як головного інструмента впливу на «душу вихованця... Умова ефективності слова вихователя - широкий зміст, різноманітність цілей звертання педагога до вихованця» (Сухомлинский, 1967, с. 40). Залежно від визначених цілей Сухомлинський підрозділяє слово педагога на такі прийоми: роз'яснення, навіювання, ознайомлення зі світом моральних ідей (сократичний метод), похвала, заохочення, покарання, осуд, висловлення недовіри, заборона, довіра, які спираються на «інтелектуальну основу повсякденного спілкування» (Сухомлинский, 1967).

Але це частина методів, що стосуються морального виховання, яке він ставив серед усіх напрямів виховання на перше місце. У частково опублікованій праці Василя Олександровича «Методика морального виховання» $\epsilon$ розділ «Сутність методів виховання», де педагог перелічив і дав свій коментар 26-ти методам, серед них (курсивом позначаємо ті, які були названі в «Етюдах») :

- праця;

- суспільна діяльність;

- пізнання й охорона природи;

- створення краси;

- піклування про живе і красиве;

- гра;

- художнє читання, казка, драматизація, музика; зображальне мистецтво;

- спонука до оволодіння знаннями, до пізнання світу, людини, краси, до самоосвіти;

- самопізнання,

- самоаналіз, самовдосконалення;

- слово учителя (роз'яснення, навіювання, переконання, роздуми, розмисли, спонука, похвала, осуд);

- духовна боротьба;

- формування, розвиток, збагачення духовних потреб;

- творчість;

- особистий приклад;

- обмін духовними багатствами в колективі;

- змагання творчих здібностей;

- вправляння і формування звичок;

- режим і традиції;

- висловлювання довіри,

- висловлювання недовіри;

- обмеження бажань;

- спостереження, вивчення духовного світу;

- заохочення,

- примус,

- покарання (Сухомлинский, с. 82-143).

Ознайомлюючись 3 методами виховання, висунутими й обгрунтованими Сухомлинським, розуміємо специфіку його авторського бачення методів, яке базується на його педагогічній концепції, основою якої $\epsilon$ цілісна гуманістична й дитиноцентрична філософія, що об'єднує у собі як дидактичні, так і виховні аспекти, створюючи тим самим єдиний вимір «гармонії педагогічних впливів», поєднує знання і почуття як єдиний шлях руху до поставленої мети.

Педагог у своїй праці особливого значення надавав розділу про методи, про що писав у листі до заступника головного редактора журналу «Народное образование» О. Бойму, де й друкувалися «Етюди»: «Ще раз дуже Вас прошу, дайте матеріал про 
методи» (Сухомлинська, 2008). Але редакція не виконала прохання автора, дала дуже урізаний уривок цього розділу і припинила публікацію.

У цьому неопублікованому рукописі особливо цікавим, як на мене, виявився невеликий параграф під назвою «Специфіка виховання у порівнянні з освітою», у якому Сухомлинський перераховує і пояснює, чим, на його думку, відрізняється одна складова педагогічних впливів від іншої. По-перше, він вважає, що «програма (замисел, проектування людини) виховання більш стійка, постійна, незмінна, ніж програма навчання (освіти), отримання знань». Ця остання має постійно оновлюватися, а виховання, що включає в себе ази моральної культури, створеної людством, має залишатися назавжди. По-друге, перспективність процесу виховання означає більшу дистанцію між сьогоднішнім педагогічним впливом на вихованця і кінцевими результатами виховання: «зерно, посіяне сьогодні, дасть урожай через декілька років». По-третє, «у вихованні особистість того, хто виховує, відіграє значно більшу роль, ніж в навчанні», по-четверте, «знання наукової істини і є освіта; знання моральних істин не $є$ виховання...[а] стає фактором моральності лише тоді, коли знання переломлюються в активній діяльності особистості». I, no-n'яте, розумове виховання має свої обмеження в силу задатків кожної особистості, тоді як «удосконалення людини безкінечно і не має меж удосконалення іiі краси, багатства духовного світу» (Сухомлинский, 1967, с.148-150).

Висновки і перспективи подальших розвідок. Матеріали, викладені у статті, i особливо ті, що стосуються маловідомих або ж неопублікованих сторінок творчої спадщини педагога, можуть, на нашу думку, стати предметом аналізу як дослідників, так і учительства, особливо з розгортанням діяльності нової реформованої української школи. Вважаємо, що такі матеріали розширюють арсенал методів як навчання, так і виховання, показують як їх методологічну й теоретичну єдність, взаємозалежність і взаємовплив, так i, що не менш важливо, їхню відмінність у змістовому наповненні й темпоральному вимірі. Останнє особливо важливо в нинішніх умовах плинності й непередбачуваності, хаотичності суспільних явищ, які відображаються на спрямованості освітнього процесу в цілому. I тут спадщина Василя Сухомлинського подає достатньо прикладів вдалого застосування методичних знахідок, які дійшли до сьогодення, розвинулися у часі й мають перспективу подальшого розвитку.

\section{СПИСОК ВИКОРИСТАНИХ ДЖЕРЕЛ}

Гончаренко, С. (2000). Методика як наука. Шлях освіти. № 1. С. $3,5$.

Енциклопедія освіти. (2008). Київ: Юрінком Інтер. С.488-490.

Сухомлинський, В. (1971). Методика виховання колективу. Київ: Рад. школа. 208c.

Сухомлинський, В. (1946). Підвищити якість знань учнів 3 арифметики в початковій школі. Удар. прачя. 3 січня.

Сухомлинський, В. (1951). Рішуче поліпшити якість програм з української літератури і літературного читання. Рад. освіта. 4 серпня.

Сухомлинський, В. (1951). Робота над творами у 8 - 10 класах. Укр. мова в шк. № 4. C.62-68.

Сухомлинський, В. (1952). Навчання мови в 1-4 класах. Укр. мова в шк. № 4. С.4958.

Сухомлинський, В. (1953). Повторення пройденого і засвоєння нового Рад. освіта. 18 квіт.

Сухомлинський, В. (1954). Уроки заключного повторення і систематизації вивченого. Рад. шк. № 4. С.26-31.

Сухомлинський, В. (1959). Відповідність методів навчання змісту і меті уроку. Рад. шк. № 11. С. 9-12.

Сухомлинський, В. (1965). Слово рідної мови. Укр. мова і літ. в шк. № 5. С.47-54.

Сухомлинський, В. (1968). Слово рідної мови. Укр. мова і літ. в шк. № 12. С.1-10.

Сухомлинський, В. (1969). Думки про літературу в школі. Літ Україна. 26 верес. 
Сухомлинський, В. (1969). Стежка до квітучого саду. Літ Україна. 26 верес.

Сухомлинський, В. (1987). Павлиська середня школа [Розділ V. Розумове виховання. Параграф Розумове виховання і питання методики навчання]. Вибрані твори в 5-ти т. T. IV. Київ. С.270 - 286.

Сухомлинський, В. (2018). Серче віддаю дітям [Як ми вчимося читати й писати]. Харків: Акта. С. $146-159$.

Сухомлинський, В. (1976). Сто порад учителеві [Параграфи: 8. Про збереження в пам'яті школяра елементарних знань (с.445-447); 9. «Дві програми навчання», розвиток мислення школярів (с.447-449);11. Знання - мета, і засіб (с.452-454); 12. Про добування знань (с. 454-456); 13. Як вести учнів від фактів до абстрактних істин (с.456$458)$; 14. Перше вивчення матеріалу (с.459-460); 15. Осмислювання нового матеріалу як етап уроку (с. 461-463); 16. Як перевірку виконання домашніх завдань зробити ефективною розумовою працею (с. 463-464); 17. Оцінки мають бути вагомими (с. $465-$ $466) ; 18$. Мати навчання не повинна стати мачухою (с.466-468); 19. Як бути 3 перевіркою зошитів (с.468-470); 20. Зміст активної діяльності учнів під час вивчення предмета (с.470-472); 24. Не допускайте диспропорції між уміннями і знаннями (с.475478); 31. Щоб не було перевантажень, потрібен вільний час (с. 492- 495); 35. Як добитися, щоб учні були уважними (с.501-503); 36. Наочність - стежка пізнання і світло, що осяває цю стежку (с.504-507)]. Вибрані твори. В 5-ти т. T. 2. С.417-654.

Святовець, В. (1974). Вимоги В.О. Сухомлинського до уроків мови та літератури. Укр. мова і літ. в ик. № 10. С.75-78.

Святовець, В. (1978). Аналізи уроків в педагогічній практиці В.О. Сухомлинського. Рад. шк. № 9. С. 48-51.

Святовець, В. (1978). Про уроки літератури в Павлиській школі. Укр. мова і літ. 8 шк. № 9. С. 61-67.

Стельмахович, М. (1985). В.О. Сухомлинський про розвиток зв'язного мовлення учнів.Укр. мова і літ в шк. № 7. С.46-55.

Стельмахович, М. (1988). Видатний творець методики вивчення української мови. Укр. мова і літ. в шкк. № 9. С. 52-60.

Мамчур, Л. (2009). Лінгводидактична спадщина В. О. Сухомлинського: навч.метод. посіб. Умань: Софія. 170 с.

Баранюк, I. (2017). Слово, природа, краса в педагогічній системі Василя Сухомлинського. Кропивницький: «Імпекс-ЛТД». 252 с. [Розділ 3. Практична лінгводидактика (1. Про «золоті правила» Учителя учителів (с.63-67); 2. Аналіз уроків у 1-му класі (с.67-75); 3. Аналіз уроків у 2-му класі (с.75-82); 4. Аналіз уроків у 3-му класі (с.82-101); 5. Вузлики на пам'ять або про «золоті правила» для вчителя початкової школи (с. 108-112)].

Пархета, Л. (2006). Українська література як навчальний предмет у спадщині B. О. Сухомлинського. Кандидат педагогічних наук. Уманський державний педагогічний університет ім. П. Тичини. Умань. 20 с.

Сухомлинський, В. (1988). Розмова з молодим директором. Київ: Рад. школа. C.223.

Зошит. Аналіз уроків за 1969/1970 рік. 20.Х.1969 р. Урок украӥнськоӥ мови. 7-б клас. Особистий архів О. Сухомлинської. С.79.

Сухомлинский, В. О. Биобиблиография. (1987). [упор. А.І. Сухомлинська, О. В. Сухомлинська]. Київ : Рад. шк. 255 с.;

Сухомлинський В. Біобібліографія: 1987-2000 рр. (2001) [уклад. Г. І. Сухомлинська, О. В. Сухомлинська]. Київ. 128 с.;

Сухомлинський В.Біобібліографія: 2001-2008 рр. (2008) [упор. Л. Заліток]. Київ: Богданова А.М. 196 с.

Сухомлинський Василь. Серие віддаю дітям. Нове прочитання. (2018). 2-е видання. Харків: Акта. С.74-123. 
Сухомлинский, В. (1967). Этюды о коммунистическом воспитании. Нар. образование. № 12. С.40-43.

Сухомлинский, В. Методика нравственного воспитания. Рукопис машинописного авторизованого тексту. Особистий архів О. Сухомлинської. 592 с.

Этюды о В. А. Сухомлинском. (2008). Педагогические апокрифы [упор. О. Сухомлинська]. Харків: Акта. С.62.

\section{REFERENCES}

Honcharenko, S. (2000). Metodyka yak nauka [Methodology as a Science] Shliakh osvity. No 1. S. 3, 5. (in Ukrainian)

Entsyklopediia osvity. (2008). [Encyclopedia of Education]. Kyiv: Yurinkom Inter. S.488-490. (in Ukrainian)

Sukhomlynskyi, V. (1971). Metodyka vykhovannia kolektyvu [Methods of Education of the Collective]. Kyiv: Rad. shkola. 208 s. (in Ukrainian)

Sukhomlynskyi, V. (1946). Pidvyshchyty yakist znan uchniv z aryfmetyky v pochatkovii shkoli [Improve the Quality of Knowledge in Arithmetic in Primary School]. Udar.pratsia. 3 sichnia. (in Ukrainian)

Sukhomlynskyi, V. (1951). Rishuche polipshyty yakist prohram z krainskoi literatury i literaturnoho chytannia [Improving the Quality of Programs in Ukrainian Literature and Literary Reading]. Rad. osvita. 4 serpnia. (in Ukrainian)

Sukhomlynskyi, V. (1951). Robota nad tvoramy u 8-10 klasakh [Work on compositions in 8-10 grades]. Ukr. Mova $v$ shk. No 4. S.62-68. (in Ukrainian)

Sukhomlynskyi, V. (1952). Navchannia movy v 1-4 klasakh [Teaching Language in 1-4 grades]. Ukr. mova $v$ shk. No 4. S.49-58. (in Ukrainian)

Sukhomlynskyi, V. (1953). Povtorennia proidenoho i zasvoiennia novoho [Review of What Has Been Learned and Assimilation of New]. Rad. osvita. 18 kvit. (in Ukrainian)

Sukhomlynskyi, V. (1954). Uroky zakliuchnoho povtorennia i systematyzatsii vyvchenoho [Lessons on the Final Review and Systematization of What Has Been Learned]. Rad. shk. No 4. S.26-31. (in Ukrainian)

Sukhomlynskyi, V. (1959). Vidpovidnist metodiv navchannia zmistu i meti uroku [Revelance of Teaching Methods of Content and Purpose of the Lesson]. Rad. shk. No 11. S. 9-12. (in Ukrainian)

Sukhomlynskyi,V. (1965). Slovo ridnoi movy [A Word of the Native Language). Ukr. mova i lit. $v$ shk. No 5. S.47-54. (in Ukrainian)

Sukhomlynskyi, V. (1968). Slovo ridnoi movy [A Word of the Native Language). Ukr. mova i lit. $v$ shk. No 12. S.1-10. (in Ukrainian)

Sukhomlynskyi, V. (1969). Dumky pro literaturu v shkoli [Thoughts about Literature in School). Lit Ukraina. 26 veres. (in Ukrainian)

Sukhomlynskyi, V. (1969). Stezhka do kvituchoho sadu [The Path to the Flowering Garden]. Lit Ukraina. 26 veres. (in Ukrainian)

Sukhomlynskyi, V. (1977). Pavlyska serednia shkola [Rozdil V. Rosumove vykhovannia. Parahraf "Rozumove vykhovannia i pytannia metodyky navchannia"] [Pavlysh Secondary School [Chapter 5. Mental Education. Paragrarh "Mental Education and Issues of Teaching Methods]). Vybrani tvory v 5-ty t. T.IV. Kyiv. S.270-286. (in Ukrainian)

Sukhomlynskyi, V. (2018). Sertse viddaiu ditiam [Yak my vchymosia chytaty i pysaty] [How We Learn to Read and Write]) [I Give My Heart to Children]. Kharkiv: Akta. S.146159. (in Ukrainian)

Sukhomlynskyi, V. (1976). Sto porad uchytelevi [Parahrafy: 8. Pro zberezhennia v pamiati shkoliara elementarnykh znan [One Hundred Tips for the Teacher. Paragraph 8. About Keeping Elementery Knowledge in the Memory of the Students] (s.445-447); 9. "Dvi prohramy navchannia", rozvytok myslennia shkoliariv ["Two Training Programs" Development the Student's Thinking (s.447-449); 11. Znannia - meta, i zasib [Knowledge is the Goal and the Tools] (s.452-454); 12. Pro dobuvannia znan [About Gaining Knowledge] (s. 454-456); 13. Yak vesty uchniv vid faktiv do abstraktnykh istyn [How to Guide Students 
from Facts to Abstract Truth] (s.456-458); 14. Pershe vyvchennia materialu [The First Study of the Material] (s.459-460); 15. Osmysliuvannia novoho materialu yak etap uroku [Understanding New Material as a Stage at the Lesson] (s. 461-463); 16. Yak perevirku vykonannia domashnikh zavdan zrobyty efektyvnoiu rozumovoiu pratseiu How to Make Checking Students' Homework an Effective Mental Work] (s. 463-464); 17. Otsinky maiut buty vahomymy [Marks Should Be Significant] (s. 465-466); 18. Maty navchannia ne povynna staty machukhoiu Mother of Learning Should not Become a Stepmother] (s.466468); 19. Yak buty z perevirkoiu zoshytiv [How to Check Copybooks] (s.468-470), 20. Zmist aktyvnoi diialnosti uchniv pid chas vyvchennia predmeta [Content of Active Activity of Students While Studying] (s.470-472); 24. Ne dopuskaite dysproportsii mizh uminniamy i znanniamy [Avoid Disproportion between Skills and Knowledge] (s.475-478); 31. Shchob ne bulo perevantazhen, potriben vilnyi chas [In Order to Avoid Overload, You Need Free Time] (s. 492- 495); 35. Yak dobytysia, shchob uchni buly uvazhnymy [How to Make Students Attentive] (s.501-503); 36. Naochnist - stezhka piznannia i svitlo, shcho osiavaie tsiu stezhku [Visuality as the Way to Knowledge and the Light That Illuminates This Way] (s.504-507)]. V.O. Sukhomlynskyi . Vybrani tvory. V 5-ty t. T. 2. S.417-654. (in Ukrainian)

Sviatovets, V. (1974). Vymohy V.O. Sukhomlynskoho do urokiv movy ta literatury [Requirements of V.O.Sukhomlynskyi to the Language and Literature Lessons] Ukr. mova $i$ lit. $v$ shk. No 10. S.75-78. (in Ukrainian)

Sviatovets, V. (1978). Analizy urokiv v pedahohichnii praktytsi V.O. Sukhomlynskoho [Analysis of Lessons in Pedagogical Practice of Sukhomlynskyi]. Rad.shk. No 9. S.48-51. (in Ukrainian)

Sviatovets, V. (1978). Pro uroky literatury v Pavlyskii shkoli [About Literature Lessons at Pavlysh School].Ukr. mova i lit. v shk. No 9. S.61-67. (in Ukrainian)

Stelmakhovych, M. (1985). V. O. Sukhomlynskyi pro rozvytok zviaznoho movlennia uchniv [V. O. Sukhomlynskyi on the Development of Coherent Student Communication] Ukr. mova i lit $v$ shk. No 7. S.46-55. (in Ukrainian)

Stelmakhovych, M. (1988). Vydatnyi tvorets metodyky vyvchennia ukrainskoi movy [Prominent Creator of the Ukrainian Language Teaching Methodology]. Ukr. mova i lit. $v$ shk. No 9. S.52-60. (in Ukrainian)

Mamchur, L. (2009). Linhvodydaktuchna spadshchyna V. O. Sukhomlynskoho: navchmetod,posib. [The Linguo-didactic Heritage of V. O. Sukhomlynskyi: training manual]. Uman: Sofiia. 170 s. (in Ukrainian)

Baraniuk, I. (2017). Slovo, pryroda, krasa v pedahohichnii systemi Vasylia Sukhomlynskoho [Word, Nature, Beauty in the Pedagogical System of Vasyl Sukhomlynskyi] [Rozdil 3. Praktychna linhvodydaktyka (1. Pro "zoloti pravyla" Uchytelia uchyteliv [Section 3. Practical Linquistics (1. About the "Golden Rules" of the Teacher for Teachers] (s.63-67); 2. Analiz urokiv u 1-mu klasi [Analysis of Lessons in the $1^{\text {st }}$ Grade] (s.67-75); 3. Analiz urokiv u 2-mu klasi [Analysis of Lessons in the 2nd Grade] (s.75-82;) 4. Analiz urokiv u 3mu klasi [Analysis of Lessons in the 3d Grade] (s.82-101); 5. Vuzlyky na pamiat abo pro "zoloti pravyla" dlia vchytelia pochatkovoi shkoly [Memory Tips or "Golden Rules" for Elementary School Teachers] (s. 108-112). Kropyvnytskyi: "Impeks-LTD”. 252 s. (in Ukrainian)

Parkheta, L. (2006). Ukrainska literatura yak navchalnyi predmet u spadshchyni V.O. Sukhomlynskoho. [Ukrainian Literature as a Subject in Heritage of V.O.Sukhomlynskyi]. Kandydat pedahohichnykh nauk. Kandydat pedahohichnykh nauk. Uman. derzh. ped. un-t im. P. Tychyny. Uman. 20 s. (in Ukrainian)

Sukhomlynskyi, V. (1988). Rozmova z molodym dyrektorom [Talking to a Young School Principal]. Kyiv: Rad. shkola. S.223. (in Ukrainian)

Zoshyt. Analiz urokiv za 1969/1970 rik. 20.Kh.1969 r. Urok ukrainskoi movy. 7-b klas. [Copybook. Analysis of Lessons for 1969-1970 years. 20.X.1969. The Ukrainian Language Lesson. 7 b Grade.]. S.79. Osobystyi arkhiv O. Sukhomlynskoi. (in Ukrainian) 
Sukhomlynskyi V. Biobibliohrafiya. (1987). [V.A.Sukhomlynskyi: Biobibliography]. Upor. A. Y. Sukhomlynska, O. V. Sukhomlynska. K.: Rad. shk., 255 s. (in Russian)

Sukhomlynskyi V. Biobibliohrafiia: 1987-2000 rr. (2001). [V.O. Sukhomlynskyi: Biobibliography: 1987-2000 [Uklad. H. I. Sukhomlynska, O. V. Sukhomlynska]. Kyiv. 128 s. (in Ukrainian)

Sukhomlynskyi V. Biobibliohrafiia: 2001-2008 rr. (2008). [V.O. Sukhomlynskyi: Biography: 2001-2008]. [Upor. L. Zalitok]. K.: Bohdanova A.M. 196 s. (in Ukrainian)

Sukhomlynskyi Vasyl. Sertse viddaiu ditiam. Nove prochytannia. (2018). 2-e vydannia. Sukhomlynskyi Vasyl [I Give My Heart to the Children. New Reading]. 2-nd edition. Kharkiv: Akta. S.74-123. (in Ukrainian)

Sukhomlynskyi, V. (1967). Etyudy o kommunisticheskom vospitanii [Sketches on Communist Education]. Nar. Obrazovaniye. No 12. S.40-43. (in Russian)

Sukhomlinskiy, V. Metodika nravstvennogo vospitanyya. Rukopis mashynopisnogo avtorizovanogo tekstu [Methodolody of Moral Education. Handwriting of Typewritten Authorized Text]. 592 s. Osobystyi arkhiv O. Sukhomlynskoi. (in Russian)

Etyudy o V. A. Sukhomlinskom. Pedagogicheskiye apokryfy (2008).[Etudes about V.A.Sukhomlynskyi. Pedagogical Apocryphas] [upor. O. Sukhomlynska]. Kharkiv: Akta. S.62. (in Russian)

\title{
METHODOLOGICAL HERITAGE OF VASYL SUKHOMLYNSKYI: THROUGH HISTORICAL AND PEDAGOGICAL COGNITION TO SEARCHING ANSWERS ON CURRENT CHALLENGES
}

\author{
Olha Sukhomlynska \\ Doctor of Sciences (in Pedagogy), Professor, \\ Full Member of the National Academy of Pedagogical Sciences of Ukraine, \\ Chief Researcher at Sukhomlynskyi State National Pedagogical Library, \\ Kyiv, Ukraine \\ ORCID: 0000-0002-2033-285X \\ e-mail:2991946@gmail.com
}

\begin{abstract}
In the article the methodological system of V. Sukhomlynskyi is considered through the prism of recent history of pedagogy and modern approaches to the development of methodological problems to understand more deeply the problem in the context of actualization of the issues of organization the activity of the students during the educational process in the institutions of secondary education. The methodological heritage of the teacher as an important component of his holistic system of views on education and upbringing of children and youth is highlighted. It has been carried out historiographic analysis of the recent works of researchers who studied the methodological heritage of the teacher and on this basis, a special contribution of V. Sukhomlynskyi to the development of teaching methods in elementary grades, methods of Ukrainian literature and linguodidactics was revealed. It was disclosed the special contribution of the teacher to the development of the methodology of education, which is characterized by the combination of two methods education and upbringing - into a single integral whole, that embodied in innovative forms of activity created by him, aimed at the development of children, which were fundamentally different from the approaches and forms of organization of the educational process existing at that time (school of joy, lessons of thinking, lessons of creativity, intellectual background of school, humanization of knowledge, joy of knowledge, harmony of pedagogical influences, etc.).

In addition to the historiography of materials on the methodological heritage of the teacher, the article also explores the little researched problem - analysis of lessons attended by V. Sukhomlynskyi at school where he worked, as well as materials from a partially
\end{abstract}


unpublished manuscript which expands and deeps knowledge about V. Sukhomlynskyi as a methodologist.

It has been found that the methodological heritage of the teacher, which contains both educational components, is a holistic methodological approach to pedagogical process, occurring in educational institutions, and is the most responsive to the latest trends in education.

It was concluded, that modern education reform as the implementation of the ideas and provisions of the New Ukrainian School, contributes to a wider familiarization with the creative achievements of the teacher and creates the preconditions for considering the methodological ideas of V.Sukhomlynskyi as components of the development of modern education in Ukraine.

It is concluded that modern education reform as the implementation of the ideas and provisions of the New Ukrainian school, contributes to a wider familiarization with the creative achievements of the teacher and creates the preconditions foe considering the methodological ideas of V. Sukhomlynskyi as components of the development of modern education in Ukraine.

Through historical and pedagogical cognition and rethinking it was introduced fruitful ideas, forms and methods of organizing the educational process contributing to the affirmation of the view of $\mathrm{V}$. Sukhomlynskyi as a harbinger of the reform process in education, reform of pedagogy.

Keywords: methodology, heritage, V. Sukhomlynskyi, research, linguodidactics, primary education, education, upbringing, analysis, lesson, pedagogical process, reform, renovation.

Стаття надійшла до редакиії 08.08.2019 р. 